\title{
Role of PET/CT in the detection of liver metastases from colorectal cancer
}

\section{Ruolo della PET/TC nel rilevamento delle metastasi epatiche da carcinoma del colon-retto}

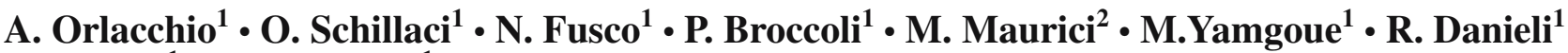 \\ S. D'Urso' ${ }^{1}$ G. Simonetti ${ }^{1}$
}

\begin{abstract}
${ }^{1}$ Dipartimento di Diagnostica per Immagini, Imaging Molecolare, Radiologia Interventistica e Radioterapia, ${ }^{2}$ Dipartimento di Sanità Pubblica, Cattedra di Igiene, Policlinico Universitario "Tor Vergata", Viale Oxford 81, 00133 Roma, Italy

Correspondence to: A. Orlacchio, Tel: +39-06-20902400, Fax: +39-06-20902404, e-mail: aorlacchio@uniroma2.it;

aorlacchio@sirm.org
\end{abstract}

Received: 1 May 2008 / Accepted: 8 July 2008 / Published online: 14 May 2009

(C) Springer-Verlag 2009

\begin{abstract}
Purpose. The aim of this study was to compare the diagnostic accuracy of 2-[fluorine-18] fluoro-2-deoxy-Dglucose positron emission tomography $\left({ }^{18} \mathrm{~F}\right.$-FDG-PET $)$ and computed tomography (CT) with PET/CT in the detection of liver metastases during tumour staging in patients suffering from colorectal carcinoma for the purposes of correct surgical planning and follow-up.

Materials and methods. A total of 467 patients underwent a PET/CT scan using an iodinated contrast medium. We compared images obtained by the single PET scan, the single CT scan and by the fusion of the two procedures (PET/CT). The final diagnosis was obtained by histological examination and/or by the follow-up of all patients, including those who did not undergo surgery or biopsy.

Results. The PET scan had $94.05 \%$ sensitivity, $91.60 \%$ specificity and $93.36 \%$ accuracy; the CT scan had $91.07 \%$ sensitivity, $95.42 \%$ specificity and $92.29 \%$ accuracy. The combined procedures (PET/CT) had the following values: sensitivity $97.92 \%$, specificity $97.71 \%$ and accuracy $97.86 \%$.

Conclusions. This study indicates that PET/CT is very useful in staging and restaging patients suffering from colorectal cancer. It was particularly useful when recurrences could not be visualised either clinically or by imaging despite increasing tumour markers, as it guaranteed an earlier diagnosis. PET/CT not only provides high diagnostic performance in terms of sensitivity and
\end{abstract}

\begin{abstract}
Riassunto
Obiettivo. Comparare l'accuratezza diagnostica della ${ }^{18}$ F-FDG-PET e della TC con quella della PET/TC nel rilievo di metastasi epatiche in pazienti affetti da carcinoma del colon-retto in fase di staging ai fini di un corretto planning chirurgico e follow-up.

Materiali e metodi. Sono stati valutati 467 pazienti mediante PET/TC effettuata con somministrazione di MdC organoiodato. È stata effettuata una comparazione tra le immagini ottenute dalla sola rilevazione PET, dalla sola rilevazione TC e quelle ottenute mediante fusione PET/TC. La diagnosi definitiva è stata ottenuta mediante conferma istologica elo attraverso il follow-up di tutti i pazienti, anche di quelli non sottoposti a procedure bioptiche o ad intervento chirurgico.
\end{abstract}

Risultati. La tecnica PET è risultata avere una sensibilità pari al 94,05\%, una specificità pari al 91,60\% ed un'accuratezza del 93,36\%; la tecnica TC una sensibilità pari al 91,07\%, una specificità pari al 95,42\% ed un'accuratezza del 92,29\%. La tecnica combinata (PET/TC) è risultata avere una sensibilità pari al 97,92\%, una specificità pari al $97,71 \%$, ed un'accuratezza del $97,86 \%$.

Conclusioni. La PET/TC è risultata di notevole utilità nella stadiazione e ristadiazione dei pazienti affetti da tumore del colon-retto. Essa è risultata particolarmente efficace quando, pur in presenza di un innalzamento progressivo dei marcatori, non era visualizzabile clinicamente o strumentalmente ripresa di malattia, 
specificity, enabling modification of patient treatment, but it is also a unique, high-profile procedure that can produce cost savings.

Keywords FDG-PET/CT · Colorectal cancer · Staging · Liver metastases $\cdot$ Recurrence garantendo così un'anticipazione diagnostica. La PET/TC non solo offre una performance diagnostica ottimale in termini di sensibilità e specificità, permettendo peraltro di modificare l'iter terapeutico del paziente, ma riveste anche caratteri di indagine unica di elezione, con conseguenti risparmi economici.

Parole chiave FDG-PET/TC - Carcinoma colon-rettale . Stadiazione $\cdot$ Metastasi epatiche $\cdot$ Recidiva

\section{Introduction}

Colorectal cancer has an elevated incidence in Western countries and is the second most frequent cause of death from cancer in both genders in Europe and the United States [1]. In Italy there are approximately 46,000 new cases each year, with a 5-year survival rate of 58\% [2]. Liver metastases are a common occurrence in the history of patients affected by colorectal cancer, with an incidence of $20 \%$ at the time of diagnosis and $>50 \%$ during the course of the disease [3]. In $15 \%-30 \%$ of cases, the metastases manifest exclusively in the liver at the same time or months or years after diagnosis of the primary tumour of the colon or rectum. The natural history of the disease shows that once they have been identified, liver metastases are destined to increase in size and number.

Hepatic resection of metastatic lesions is considered the most effective treatment option in terms of increased survival $[4,5]$, although few patients are able to undergo radical surgery at the time of diagnosis (owing to lesion site, multifocal involvement and/or insufficient residual liver function), and the 5-year survival rate after surgery is only $20 \%-50 \%$ [6]. Indeed, following surgical resection of liver metastases, many patients present with local tumour recurrence months after surgery. Tumour recurrence and surgical failure may be due to inadequate initial evaluation of the metastatic disease. Performing a detailed preoperative diagnostic study is therefore of prime importance for accurately defining the exact number and precise location of hepatic metastases. To date, the imaging modalities used for this purpose have been ultrasonography, contrast-enhanced computed tomography (CT) and magnetic resonance imaging (MRI). However, given the poor long-term results obtained, these modalities are evidently unable to guarantee an accurate preoperative assessment [7].

The impact of positron emission tomography (PET) on the quality of pretreatment diagnostic staging has been demonstrated in many tumours, including colorectal carcinoma. Retrospective studies have shown that PET provides a better preoperative selection of patients with colorectal cancer and secondary lesions, which after resection of liver

\section{Introduzione}

Il cancro del colon-retto presenta un'elevata incidenza nel mondo occidentale ed è la seconda causa di mortalità per neoplasia in ambedue i sessi sia in Europa che negli Stati Uniti [1]. In Italia, in particolare, i nuovi casi sono ogni anno circa 46000 con sopravvivenza a 5 anni del 58\% [2]. Nella storia dei pazienti affetti da neoplasia del colon-retto, le metastasi epatiche rappresentano un'evenienza comune, presentandosi nel $20 \%$ dei casi al momento della diagnosi ed in oltre il 50\% nel corso della malattia [3]. Nel 15\%-30\% dei casi le metastasi si manifestano esclusivamente al fegato contestualmente o a distanza di mesi o di anni dal momento della diagnosi del tumore primitivo del colon o del retto. La storia naturale della malattia indica che, una volta individuate, le metastasi epatiche sono destinate ad accrescersi di volume e ad aumentare di numero.

La resezione epatica delle lesioni metastatiche è l'approccio terapeutico finora ritenuto più efficace in termini di aumento della sopravvivenza [4, 5], ma solo pochi pazienti sono radicalmente operabili al momento della diagnosi (in relazione alla localizzazione, al coinvolgimento multifocale elo in ragione di una insufficiente funzionalità epatica residua) e la sopravvivenza a 5 anni dopo la chirurgia è solo del 20\%-50\% [6]. Numerosi pazienti infatti, in seguito a resezione chirurgica delle metastasi epatiche, possono presentare a distanza di mesi una recidiva tumorale locale. La recidiva neoplastica e l'insuccesso chirurgico possono essere dovute ad una valutazione iniziale inadeguata della malattia metastatica. È dunque assolutamente necessario effettuare uno studio diagnostico pre-operatorio approfondito per definire con accuratezza l'esatto numero e la precisa localizzazione delle lesioni secondarie epatiche. Finora le tecniche diagnostiche utilizzate a questo scopo sono state l'ecotomografia, la tomografia computerizzata (TC) con mezzo di contrasto (MdC), la risonanza magnetica (RM) ma, in considerazione degli scarsi risultati ottenuti a lungo termine, evidentemente esse da sole risultano insufficienti non riuscendo a garantire un'accurata valutazione pre-chirurgica [7].

L'impatto della PET (tomografia a emissione di positroni) sulla qualità dello staging diagnostico pre-terapeutico 
metastases translates into longer survival [8]. Due to its intrinsic characteristics as a functional examination, PET is in fact able to provide functional characterisation of the lesions. This occurs because the tracer used - usually 2[fluorine-18] fluoro-2-deoxy-D-glucose $\left({ }^{18} \mathrm{~F}-\mathrm{FDG}\right)$, a glucose analogue labelled with fluorine - is avidly taken up by the neoplastic cells, which have a more active glucose metabolism than normal cells [9]. The metabolic information provided by FDG-PET can therefore be used to obtain a more accurate definition of the areas of malignancy and possible lymph-node involvement, as well as identifying distant metastases, as the examination provides a full-body scan [10]. Furthermore, functional/metabolic alterations can be demonstrated and located earlier than the information provided by other imaging modalities, which are based purely on anatomical dimensional criteria or vascular abnormalities. The limited morphological information provided by PET, however, creates the need for integration with conventional CT. The introduction of new hybrid PET/CT scanners is in this sense a great leap forward [11-13].

The aim of this study was to compare the diagnostic accuracy of ${ }^{18} \mathrm{~F}$-FDG-PET, CT and PET/CT in the detection of liver metastases during staging and follow-up of patients with colorectal cancer.

\section{Materials and methods}

The study involved patients referred to our department between April 2005 and December 2007 with a diagnosis of colorectal cancer and suspected liver metastases. All patients were examined with PET, contrast-enhanced CT and PET/CT. The definitive diagnosis was provided by histology and/or clinical/radiological follow-up in all patients, even those who did not undergo biopsy or surgical procedures.

PET/CT examination technique

All examinations were performed with an integrated PET/CT scanner, Discovery ST (GE, General Electric Medical Systems, Milwaukee, WI, USA). The system combines a high speed ultra 16-detector-row CT scanner with a PET scanner equipped with 10080 bismuth germinate crystals arranged in 24 rings. Patients were required to fast for at least $6 \mathrm{~h}$ prior to the examination. Before injection of the radiotracer, patients' blood glucose levels were evaluated, and ${ }^{18} \mathrm{~F}$-FDG was injected only in conditions of normal glycaemia to avoid reducing the diagnostic potential of PET as a result of the competitive effect created by high blood glucose levels. In the event of hyperglycaemia, the patient was invited to temporarily increase muscular activity to bring blood glucose below $150 \mathrm{mg} / \mathrm{dl}$. A single $370-\mathrm{MBq}$ dose of radiotracer was administered intravenously 45-60 è stato evidenziato in molti tumori, incluso il carcinoma del colon-retto. Studi retrospettivi hanno dimostrato che la PET permette una migliore selezione pre-operatoria dei pazienti con tumore del colon-retto con localizzazioni secondarie, che si traduce, dopo la resezione di metastasi epatiche, con una più lunga sopravvivenza [8]. La PET per le caratteristiche intrinseche di "indagine funzionale", è in grado infatti di fornire una caratterizzazione funzionale delle lesioni, in quanto il tracciante utilizzato, generalmente 2-[fluorine18]fluoro-2-deoxy-D-glucose) $\left({ }^{18} F-F D G\right)$, un analogo del glucosio marcato con fluoro, viene captato avidamente dalle cellule neoplastiche che presentano un metabolismo glucidico più attivo rispetto alle cellule normali [9]. Le informazioni metaboliche che fornisce la FDG-PET permettono dunque una più accurata definizione delle aree di malignità, dell'eventuale coinvolgimento linfonodale oltre all'identificazione di lesioni ripetitive a distanza in quanto l'indagine consente una scansione di tutto il corpo [10]. Inoltre le alterazioni funzionali/metaboliche possono essere dimostrate e segnalate più precocemente rispetto a quelle fornite da altre tecniche di imaging che si basano su criteri puramente anatomici dimensionali o su anomalie di vascolarizzazione. Le limitate informazioni morfologiche fornite dalla PET, rendono però necessaria l'integrazione con la TC convenzionale. L'introduzione di nuovi scanner ibridi PET/TC rappresenta a tal fine un grande passo avanti [11-13].

Lo scopo di questo studio è comparare l'accuratezza diagnostica della ${ }^{18} \mathrm{~F}-F D G-P E T$, della TC e quella della PET/TC nel rilievo di metastasi epatiche in pazienti affetti da neoplasie del colon-retto in fase di stadiazione e nel follow-up.

\section{Materiali e metodi}

Lo studio ha riguardato i pazienti, giunti presso il nostro Dipartimento nel periodo compreso tra aprile $2005 e$ dicembre 2007, con diagnosi di neoplasia del colon e del retto con sospetto di metastasi epatiche valutate mediante PET, TC e PET/TC con MdC organo-iodato. La diagnosi definitiva è stata ottenuta mediante conferma istologica e/o attraverso il follow-up clinico-radiologico di tutti i pazienti, anche di quelli non sottoposti a procedure bioptiche o ad intervento chirurgico.

Tecnica di esecuzione dell'esame PET/TC ms

Tutti gli esami sono stati eseguiti con uno scanner integrato PET/TC ms Discovery ST (GE, General Electric, Medical Systems, Milwaukee,WI, USA). Tale sistema combina uno scanner TC modello High Speed Ultra con 16 file di detettori con un tomografo PET con 10080 cristalli di germinato di bismuto $(B G O)$ disposti in 24 anelli. Il paziente è stato tenuto a digiuno per almeno 6 ore. Prima dell'iniezione del radiofarmaco si è provveduto alla valutazione della glicemia, 
min before the examination. During this phase, the patient was kept in a quiet environment to limit muscle activity and thereby reduce radiotracer accumulation in skeletal muscle. The patient was also adequately hydrated with intravenous saline solution (250-500 $\mathrm{ml}$ ) to reduce pooling of the radiotracer in the renal collecting system. At the same time, a single dose of approximately $900 \mathrm{cc}$ of a solution containing contrast material (Gastrografin-370 mgI/ml, Schering AG, Berlin, Germany) was administered orally to adequately opacify the bowel loops according to a protocol implemented in the department.

The examination was performed with the patient lying supine inside the gantry with arms above the head and began with a scout scan. A baseline CT scan was then acquired with low tube current ( $80 \mathrm{~mA})$ to correct the attenuation for the PET study. The following scan parameters were used: $140 \mathrm{kV}$ to obtain good quality images at the level of the shoulder and pelvic girdles; $80 \mathrm{~mA}$; FOV 420-500 mm; CT slice thickness $3.75 \mathrm{~mm}$ (retrospectively reconstructed to $1.25 \mathrm{~mm}$ ) to approximate the width of the PET section; slice interval $3.27 \mathrm{~mm}$, to coincide with the spacing between the PET sections; scan speed $<1 \mathrm{~s}$ per revolution. Once the CT scan was completed, the PET scan was performed with a $2 \mathrm{D}$ technique in the caudocranial direction from the proximal third of the femurs to the head; five to six bed positions were acquired, with a duration of 4 min per bed.

Images were reconstructed using a standard iterative algorithm [ordered subsets expectation maximisation (OSEM)], with a mean duration for the PET examination of 20-24 min. PET acquisition was immediately followed by CT examination performed with the intravenous administration of $100-120 \mathrm{ml}$ of nonionic iodinated contrast medium with an injection rate of 2-3 ml/s (Iomeron-350 $\mathrm{mgI} / \mathrm{ml}$, Bracco, Milan, Italy). Two data sets were acquired: the first included the upper abdomen with a delay of $30 \mathrm{~s}$ from the beginning of the contrast injection, and the second extended from the neck to the pubic symphysis with a delay of 60-80 s. An additional scan was performed in the late phase to correctly characterise the lesions. Lastly, after having the patients place their arms by their sides, axial scans of the head were acquired.

The following scan parameters were used: $120-140 \mathrm{kV}$, automatic tube current (limit 330-350 mA), slice thickness $3.75 \mathrm{~mm}$ (retrospectively reconstructed to 1.25 ), acquisition mode 27.50/1.375:1, gantry rotation speed $0.6 \mathrm{~s}$, FOV large, matrix $512 \times 512$. The overall duration of the entire PET/CT acquisition was on average $40 \mathrm{~min}$.

Image analysis

Images were processed on an Advantage-Windows 4.2 workstation (GE, General Electric Medical Systems) individually for the PET and CT examinations and with iniettando il ${ }^{18}$ F-FDG solo in condizioni di normoglicemia per evitare di ridurre il potenziale diagnostico della PET per l'effetto competitivo dovuto ad elevati livelli glicemici. Nel caso di iperglicemia si è invitato il paziente ad incrementare temporaneamente l'attività muscolare, per riportare la glicemia al di sotto di $150 \mathrm{mg} / \mathrm{dl}$. Il radiofarmaco, nella dose di $370 \mathrm{MBq}$, è stato somministrato per via endovenosa in bolo unico 45-60 minuti prima dell'inizio dell'esame. Durante questa fase il paziente è stato tenuto in un ambiente tranquillo per limitare l'attività muscolare onde ridurre, dopo l'iniezione, l'accumulo del radiofarmaco nella muscolatura scheletrica; si è inoltre provveduto ad una adeguata idratazione mediante infusione endovena di soluzione fisiologica $(250-500 \mathrm{ml})$ per ridurre il ristagno di tracciante nell'emuntorio renale. Contemporaneamente sono stati somministrati per via orale circa 900 cc di una soluzione contenente MdC (Gastrografin, $370 \mathrm{mgI} / \mathrm{ml}$, Schering AG, Berlino, Germania) in un'unica somministrazione, per un'adeguata opacizzazione delle anse intestinali secondo il protocollo praticato nel nostro Dipartimento.

Per l'esecuzione dell'esame, il paziente viene posizionato all'interno del gantry in decubito supino, con le braccia al di sopra della testa e l'indagine inizia con uno scanogramma. Viene quindi acquisita una TC in condizioni basali a basso amperaggio (80 mA) necessaria per la correzione dell'attenuazione per lo studio PET, utilizzando i seguenti parametri: $140 \mathrm{kV}$ per ottenere immagini di buona qualità a livello del cingolo scapolo-omerale e pelvico; 80 mA; FOV: 420-500 mm; spessore della sezione TC pari a 3,75 mm (retroricostruibile a 1,25 mm) per approssimare la larghezza della sezione PET; intervallo tra le sezioni ricostruito pari a 3,27 mm, per la coincidenza con la spaziatura tra le sezioni PET; velocità di scansione inferiore a 1 secondo per rivoluzione. Terminata la TC, è stato effettuato l'esame PET con tecnica $2 D$ in direzione caudo-craniale a partire dal III prossimale dei femori fino a comprendere il cranio; sono stati acquisiti 5-6 lettini con durata di 4 minuti ognuno.

Le immagini sono state ricostruite utilizzando un algoritmo iterativo standard (OSEM, ordered subsets expectation maximization), per una durata in media dell'indagine PET pari a 20-24 minuti circa. Subito dopo l'acquisizione PET viene effettuato l'esame TC dopo somministrazione endovena di 100-120 ml di MdC organo-iodato non ionico a 2-3 ml/s (Iomeron-350 mgI/ml, Bracco, Milano, Italia) predisponendo due pacchetti susseguenti di scansioni: il primo comprendente l'addome superiore con un ritardo di 30 secondi dall'inizio dell'iniezione del MdC, il secondo esteso dal collo fino alla sinfisi pubica con un ritardo di 60-80 secondi. Un'ulteriore scansione viene effettuata in fase tardiva per una corretta caratterizzazione delle lesioni. Infine, dopo avere fatto addurre lungo il tronco gli arti superiori, si acquisiscono scansioni assiali sul cranio.

La tecnica di acquisizione è stata: 120-140 kV, amperaggio automatico (limite 330-350 mA), spessore di 3,750 $\mathrm{mm}$ (retroricostruibile a 1,25 $\mathrm{mm}$ ), modalità di acquisizione 
PET/CT fusion software. PET images were assessed for areas of increased focal metabolism that exceeded the accumulation of tracer in the anatomical region. The analysis was conducted on the images corrected for attenuation and in the case of doubt also on the uncorrected images. Acquisition data of all CT examinations were processed and retrospectively reconstructed with the following parameters: slice thickness $1.25 \mathrm{~mm}$ and interval $3.27 \mathrm{~mm}$ to coincide with the spacing between the PET sections. Attenuation changes of the lesions were then quantified in both baseline conditions and after contrast enhancement.

Images obtained with CT and PET were independently reviewed by a radiologist and nuclear physician in a doubleblind fashion. Finally, diagnostic concordance between the two techniques was assessed by another group of three radiologists and three nuclear physicians. The following criteria were considered as positive findings: evidence of at least one focal uptake of FDG in the liver on PET, and the finding of at least one focal lesion suspected to be a metastatic lesion (Figs. 1, 2).
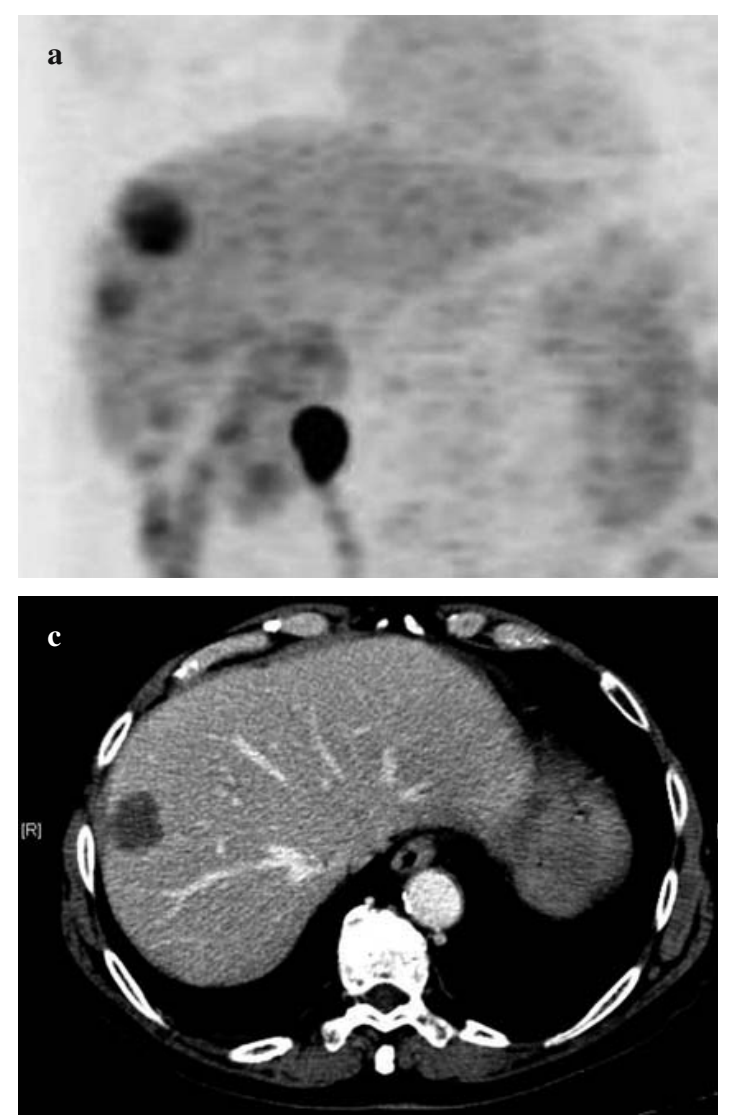

$27,50 / 1,375: 1$, velocità di rotazione del gantry di 0,6 secondi, FOV di grandi dimensioni, matrice $512 \times 512$. La durata complessiva dell'intera acquisizione PET/TC è risultata in media di circa 40 minuti.

\section{Analisi delle immagini}

Le immagini sono state rielaborate su una "workstation" Advantage-Windows 4.2 (GE, General Electric, Medical Systems), singolarmente per l'esame PET e TC e mediante ricostruzioni con software di fusione PET/TC. Sulle immagini PET è stata valutata qualsiasi area di aumentato metabolismo focale che superava l'accumulo del tracciante nella regione anatomica. Sono state esaminate le immagini corrette per l'attenuazione ed in caso di dubbio analizzate anche quelle non corrette. I dati di acquisizione di tutti gli esami TC da noi valutati sono stati rielaborati e retroricostruiti con le seguenti indicazioni: spessore delle sezioni pari a 1,25 mm ed intervallo tra le sezioni di 3,27 mm per la coincidenza con la spaziatura tra le sezioni PET. Sono state quindi quantificate le modificazioni densitometriche delle
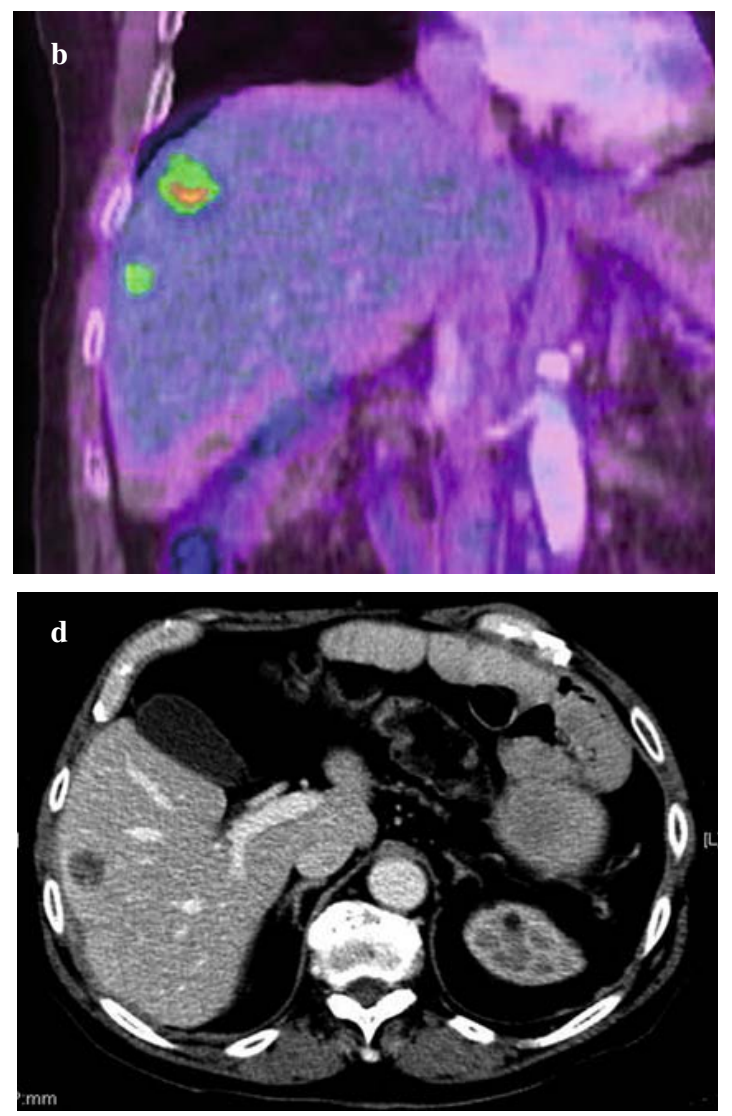

Fig. 1a-d Focal increase of 2-[fluorine-18] fluoro-2-deoxy-D-glucose ( ${ }^{18}$ F-FDG) uptake by two hepatic metastases in the right lobe in a 63-year-old man with colorectal cancer. On coronal maximum intensity projection (MIP) (a), FDG positron emission tomography (FDG-PET) and (b) fused PET contrastenhanced computed tomography (CT) images show both lesions, although they are located in different planes. Axial CT images (c,d), obtained in the portal phase, show two hepatic nodules in the VIII (c) and V (d) segments.

Fig. Ia-d Iperfissazione del tracciante in corrispondenza di due metastasi epatiche a livello del lobo di destra in un uomo di 63 anni con carcinoma del colon-retto. Nelle immagini coronali MIP FDG-PET (a) e di fusione PET/TC $(\boldsymbol{b})$ con MdC le due lesioni sono entrambe ben evidenti anche se poste su piani diversi. c,d Immagini assiali TC corrispondenti, acquisite in fase portale. Presenza di due lesioni nodulari epatiche localizzate a livello dell'VIII (c) e del $V(d)$ segmento. 

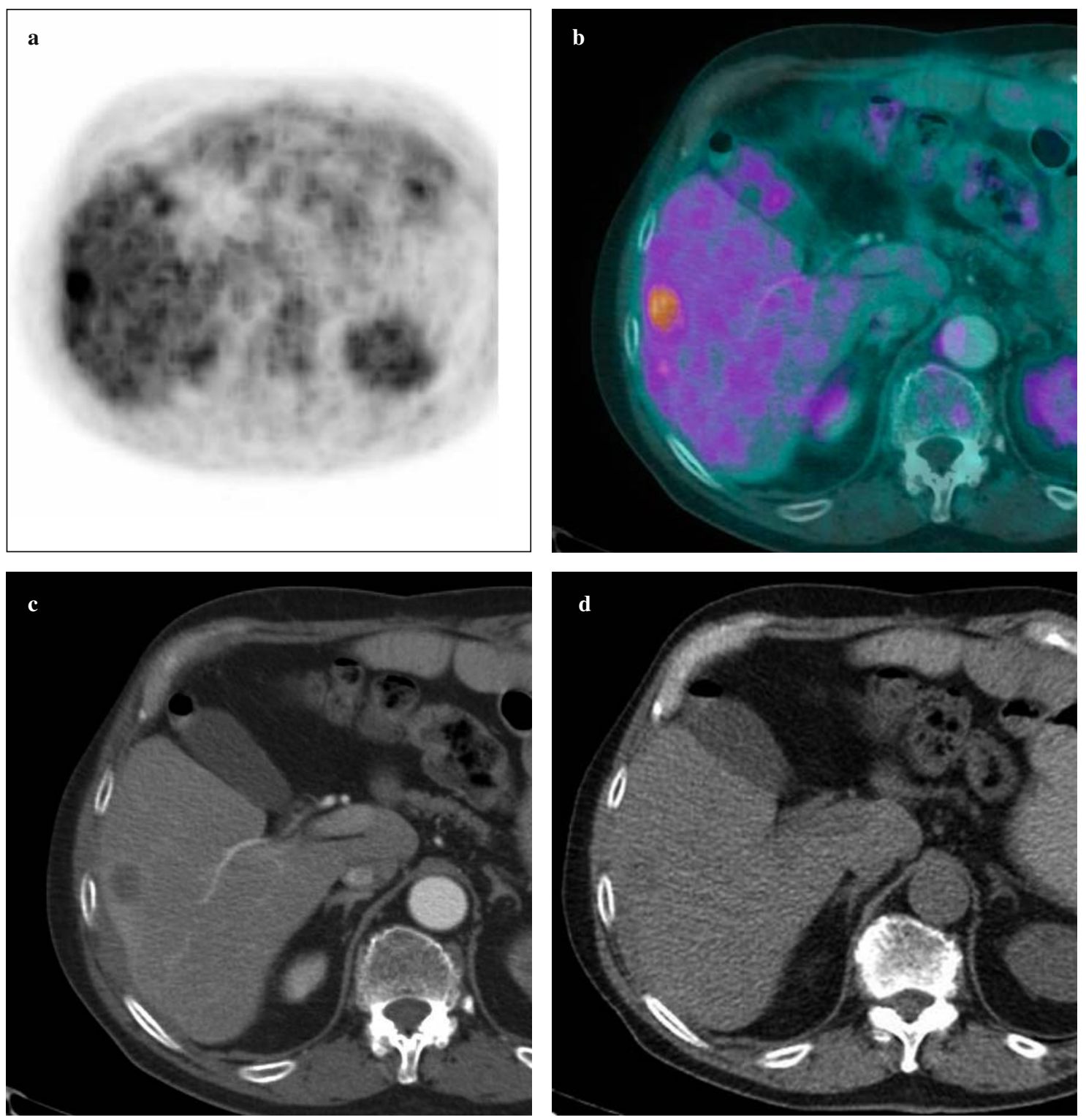

Fig. 2a-d A 75-year-old man affected by a metastasis in hepatic segment V. The axial (a) 2-[fluorine-18] fluoro-2-deoxy-D-glucose positron emission tomography $\left({ }^{18}\right.$ F-FDG-PET) image and (b) the fusion PET contrast-enhanced computed tomography (CT) images show the lesion as a focal increase of FDG uptake that corresponds to a focal hypoattenuating lesion on contrast-enhanced CT in the portal phase (c). The lesion is faintly visible on the axial unenhanced CT scan $(\mathbf{d})$.

Fig. 2a-d Uomo di 75 anni con unica metastasi epatica da ca del colon al V segmento. Nell'immagine assiale FDG-PET (a) ed in quella di fusione PET/TC (b) la lesione è riconoscibile come area di aumentato metabolismo in corrispondenza di una formazione ipodensa alla TC (c) in fase portale. $\boldsymbol{d}$ Nella scansione assiale TC basale senza mdc la lesione focale è scarsamente riconoscibile.

Statistical analysis

Data analysis was performed on the basis of the positive findings in the individual patient. For each imaging modality, we evaluated sensitivity, specificity and diagnostic accuracy with $95 \%$ confidence intervals $(95 \% \mathrm{CI})$. The difference between the individual modalities (PET and $\mathrm{CT})$ and the combined technique (PET/CT), with a statistically significant value of $p<0.05$, was estimated with the $\mathrm{Z}$ lesioni, evidenziate in condizioni basali e nella fase postcontrastografica.

Le immagini ottenute con la TC e con la PET sono state visionate e valutate indipendentemente, in doppio cieco da uno specialista radiologo e da uno specialista in medicina nucleare. Infine la concordanza diagnostica tra le metodiche è stata verificata da una ulteriore equipe di 3 medici radiologi e 3 medici nucleari. I criteri di positività da noi considerati sono stati: all'esame PET l'evidenza di almeno una 
test. In addition, we also calculated the positive predictive values (PPV) and negative predictive values (NPV) with the corresponding $95 \% \mathrm{CI}$.

\section{Results}

The study population included 467 subjects (301 men and 166 women) with a mean age of $64.4 \pm 10.2$ years (M 66.2 \pm 10.7 , F 61.2 \pm 95 ) (Table 1). The PET/CT study was conducted on all patients to identify the presence of liver metastases during staging and follow-up. Definitive diagnosis was provided by histological examination and/ or by the follow-up of all patients, even those who did not undergo biopsy or surgery. In 426 cases $(91.2 \%)$, there was concordance among the three modalities (PET, CT and PET/CT) (Figs. 1, 2). A total of 336 patients $(72 \%)$ were diagnosed as having at least one metastatic lesion in the liver at subsequent examinations [true positives (TP)].

In addition, a negative finding not in agreement with the later examinations [false negative (FN)] was obtained in 57 $(12.2 \%)$ cases. These were broken down as follows: 30 (6.4\%) FN cases at CT because no corresponding anatomical alteration was yet visible (Fig. 3); 20 (4.3\%) FN at PET due to the small lesion size $(<10 \mathrm{~mm})$, mucinous content or marked central necrosis (Fig. 4); seven (1.5\%) FN at $\mathrm{PET} / \mathrm{CT}$ resulting from the above-mentioned variables. Twenty cases $(4.3 \%)$ of false positives (FP) were identified at follow-up and/or biopsy: 11 at PET (2.4\%), six at CT

Table 1 Patient characteristics

\begin{tabular}{llll}
\hline Patients & & Number & Percent \\
\hline \multirow{2}{*}{ Gender } & & & \\
& Male & 301 & 64.5 \\
& Female & 166 & 35.5 \\
Age & & & \\
& Mean & 64.40 & \\
& Standard deviation & 10.20 & \\
\hline
\end{tabular}

Tabella 1 Casistica

\begin{tabular}{llll}
\hline Pazienti & $N$ & Percentuale \\
\hline \multirow{2}{*}{ Sesso } & & & \\
& Maschi & 301 & 64,5 \\
& Femmine & 166 & 35,5 \\
Età & & & \\
& Media & 64,40 & \\
& Deviazione standard & 10,20 & \\
& &
\end{tabular}

focale captazione dell'FDG in ambito epatico ed all'esame TC il rilievo di almeno una lesione focale sospetta per localizzazione secondaria di malattia (Figg. 1 e 2).

Analisi statistica

L'analisi dei dati è stata effettuata sulla base della positività evidenziata sul singolo paziente. Abbiamo valutato, per le tecniche in esame, la sensibilità, la specificità e l'accuratezza diagnostica con i relativi intervalli di confidenza al 95\% (IC 95\%); la differenza tra le singole metodiche (PET, $T C)$ e la combinata (PET/TC), con un valore statisticamente significativo di $p<0,05$, è stata stimata con il test $Z$. Inoltre, è stato calcolato anche il relativo valore predittivo positivo $(V P P)$ e negativo (VPN), sempre con i corrispondenti IC $95 \%$.

\section{Risultati}

Lo studio ha riguardato 467 soggetti (301 maschi e 166 femmine) di età media 64,4 anni $\pm 10,2$ (M 66,2 $\pm 10,7, F$ $61,2 \pm 9,5)$ (Tabella 1). La PET/TC è stata effettuata in tutti i pazienti con l'intento di identificare la presenza di metastasi epatiche sia in fase di stadiazione che di follow-up. La diagnosi definitiva è stata ottenuta mediante conferma istologica elo attraverso il follow-up di tutti i pazienti, anche di quelli non sottoposti a procedure bioptiche o ad intervento chirurgico. In 426 casi $(91,2 \%)$ si è ottenuto un reperto concorde per tutte le metodiche (PET, TC e PET/TC) (Figg. 1 e 2). I pazienti in cui è stata evidenziata almeno una metastasi epatica ai controlli successivi (veri positivi, VP) sono stati $336(72 \%$ del totale).

Si è ottenuto, inoltre, un reperto negativo (falsi negativi, $F N)$, non conforme ai successivi controlli, per le metodiche PET, TC e PET/TC rispettivamente in 20 (4,3\%), $30(6,4 \%)$ e $7(1,5 \%)$ casi. I risultati discordanti rispetto ai successivi follow-up hanno dimostrato: 30 casi FN alla TC poiché non era ancora visibile un'alterazione anatomica corrispondente (Fig. 3); 20 casi FN alla PET dovuti alle dimensioni delle lesioni $(<10 \mathrm{~mm})$, al contenuto mucinoso o all'importante necrosi centrale (Fig. 4); 7 casi FN alla PET/TC dovuti a una risultanza delle variabili sopracitate. I falsi positivi (FP), individuati al successivo follow-up elo all'esame bioptico, sono stati rispettivamente per la PET 11 casi $(2,4 \%)$, TC 6 casi $(1,3 \%)$ e PET/TC 3 casi $(0,6 \%)$. In base allo studio effettuato la tecnica PET è risultata avere una sensibilità pari al 94,05\% (IC 95\%: 91,52-96,58), una specificità pari al 91,60\% (IC 95\%: 86.85-96,35) ed un'accuratezza del 93,36\% (IC 95\%: 91,10-95,62) (Tabella 2); la tecnica TC una sensibilità pari al 91,07\% (IC 95\%: 88,02-94,12), una specificità pari al 95,42\% (IC 95\%: 91,84-99,00) ed un'accuratezza del 92,29\% (IC 95\%: 89,87-94,71) (Tabella 3). La tecnica combinata (PET/TC) è risultata avere una sensibilità pari al 97,92\% (IC 95\%: 

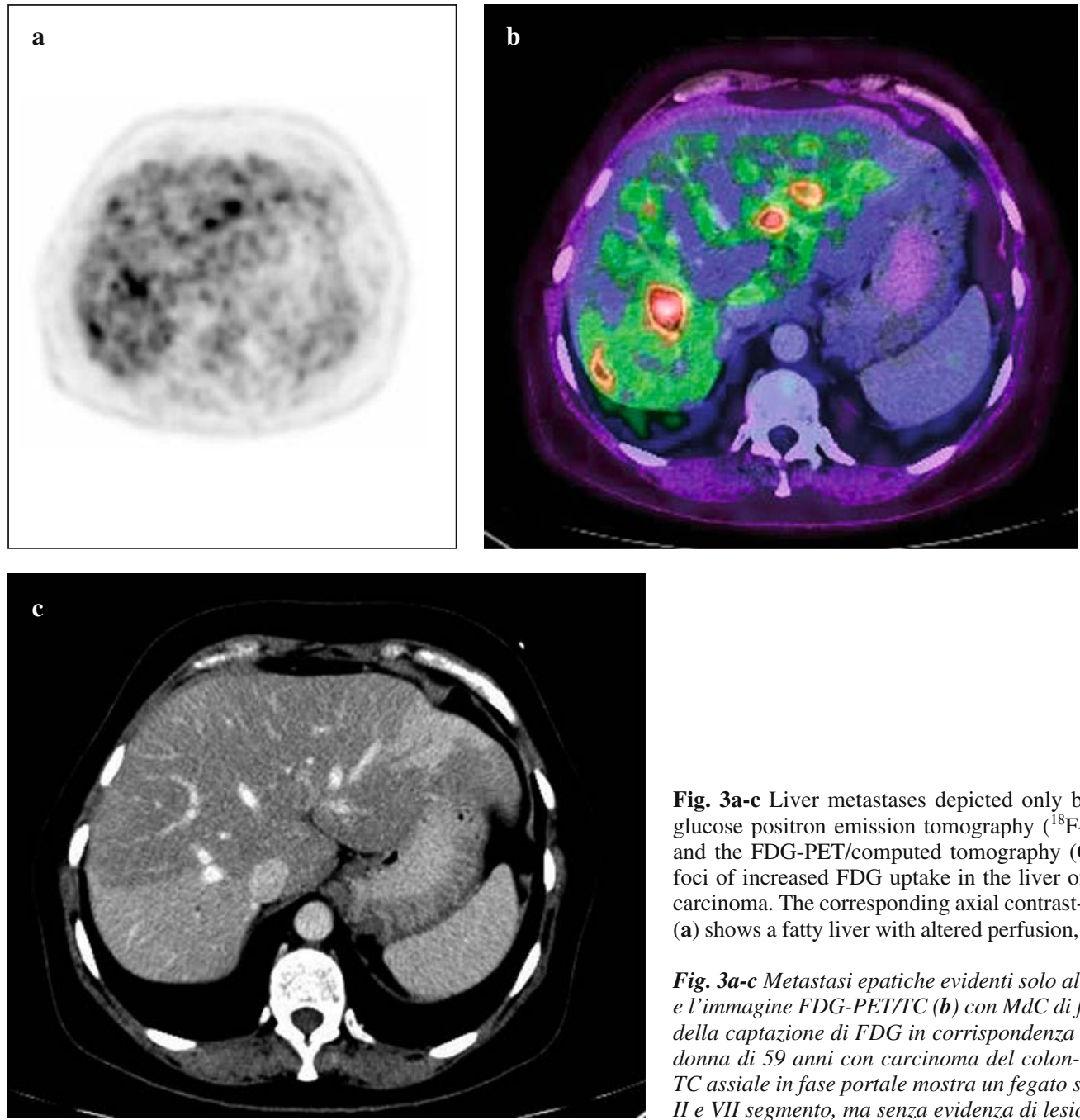

Fig. 3a-c Liver metastases depicted only by 2-[fluorine-18] fluoro-2-deoxy-Dglucose positron emission tomography $\left({ }^{18} \mathrm{~F}\right.$-FDG-PET). The axial PET scan (a) and the FDG-PET/computed tomography (CT) fusion image (b) show multiple foci of increased FDG uptake in the liver of 59-year-old woman with colorectal carcinoma. The corresponding axial contrast-enhanced CT scan in the portal phase (a) shows a fatty liver with altered perfusion, but without evidence of focal lesions.

Fig. 3a-c Metastasi epatiche evidenti solo alla PET. La scansione PET assiale (a) e l'immagine FDG-PET/TC (b) con MdC di fusione, documentano aumento focale della captazione di FDG in corrispondenza di multiple metastasi epatiche in una donna di 59 anni con carcinoma del colon-retto. c La corrispondente scansione TC assiale in fase portale mostra un fegato steatosico con alterata per fusione del II e VII segmento, ma senza evidenza di lesioni focali.

$(1.3 \%)$ and three at PET/CT $(0.6 \%)$. PET was found to have 94.05\% sensitivity (95\% CI: 91.52-96.58), 91.60\% specificity (95\% CI: 86.85-96.35) and 93.36\% diagnostic accuracy (95\% CI: 91.10-95.62) (Table 2). CT had 91.07\% sensitivity (95\% CI: 88.902-94.12), 95.42\% specificity (95\% CI: 91.84-99.00) and 92.29\% accuracy (95\% CI: 89.87-94.71) (Table 3). The combined technique (PET/CT) had $97.92 \%$ sensitivity (95\% CI: 96.39-99.44), 97.71\% specificity (95\% CI: $95.15-100)$ and $97.86 \%$ accuracy $(95 \%$ CI: 96.55-99.17) (Table 4). The PPV of PET was calculated to be $96.64 \%$ (95\% CI: 94.69-98.59), and the NPV was 85.71\% (95\% CI: 79.92-91.51) (Table 2). The PPV of CT was $98.08 \%$ (95\% CI: 96.55-99.60), and the NPV was 80.65\% (95\% CI: 74.43-86.86) (Table 3). For the combined technique, the PPV was $99.10 \%$ (95\% CI: 98.08-100) and the NPV was $94.81 \%$ (95\% CI: 91.07-98.56) (Table 4).

A statistically significant difference in sensitivity, specificity and accuracy was obtained with the $\mathrm{Z}$ test relative to the combined technique (PET/CT) vs PET. A statistically
96,39-99,44), una specificità pari al 97,71\% (IC 95\%: 95,15-100), ed accuratezza del 97,86\% (IC 95\%: 96,55-99,17) (Tabella 4). Il VPP della PET è stato stimato pari al 96,64\% (IC 95\%: 94,68-98,59), il VPN pari al 85,71\% (IC 95\%: 79,92-91,51) (Tabella 2); per quanto riguarda la TC, il VPP è stato valutato pari al 98,08\% (IC 95\%: 96,55-99,60), il VPN pari al 80,65\% (IC 95\%: 74,43-86,86) (Tabella 3). Per la tecnica PET/TC combinata il VPP è pari al 99,10\% (IC 95\%: 98,08-100), il VPN pari al 94,81\% (IC 95\%: 91,07-98,56) (Tabella 4).

L'individuazione di una differenza statisticamente significativa per sensibilità, specificità e accuratezza è stata ottenuta mediante il test $Z$ relativamente alla tecnica combinata (PET/TC) vs PET. Una differenza statisticamente significativa per sensibilità e accuratezza è stata ottenuta relativamente alla tecnica combinata (PET/TC) vs TC. Non è stata evidenziata alcuna differenza statisticamente significativa di sensibilità, specificità e accuratezza tra le singole tecniche (PET vs TC) (Tabella 5). 

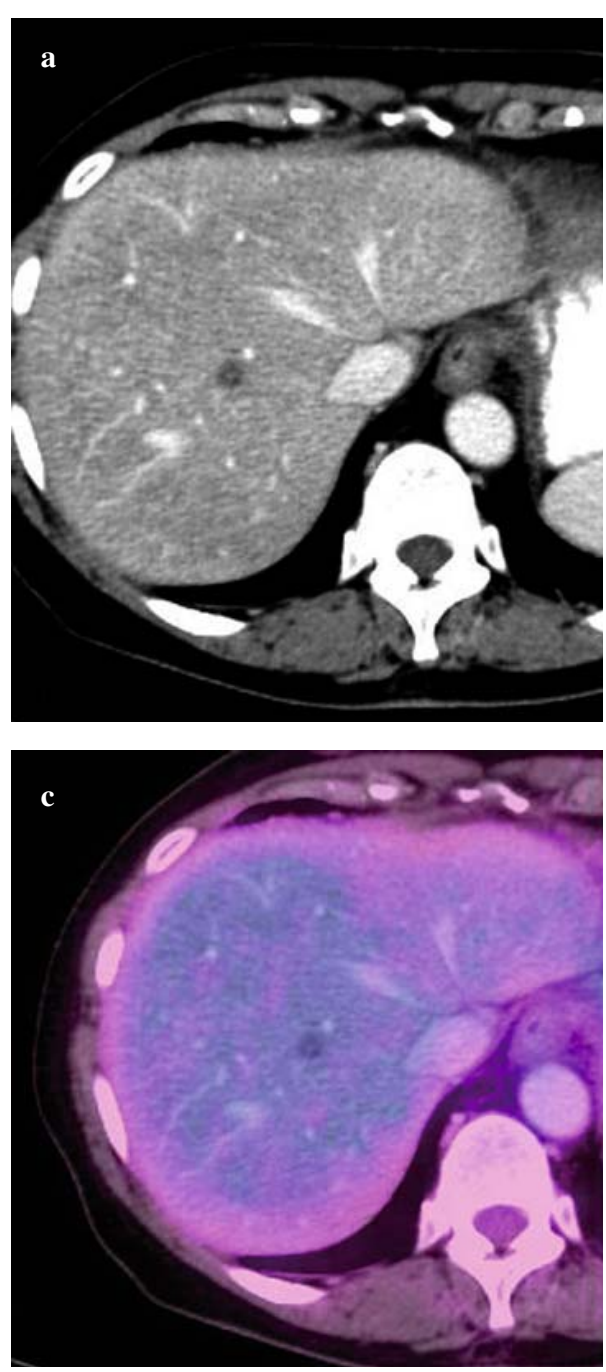

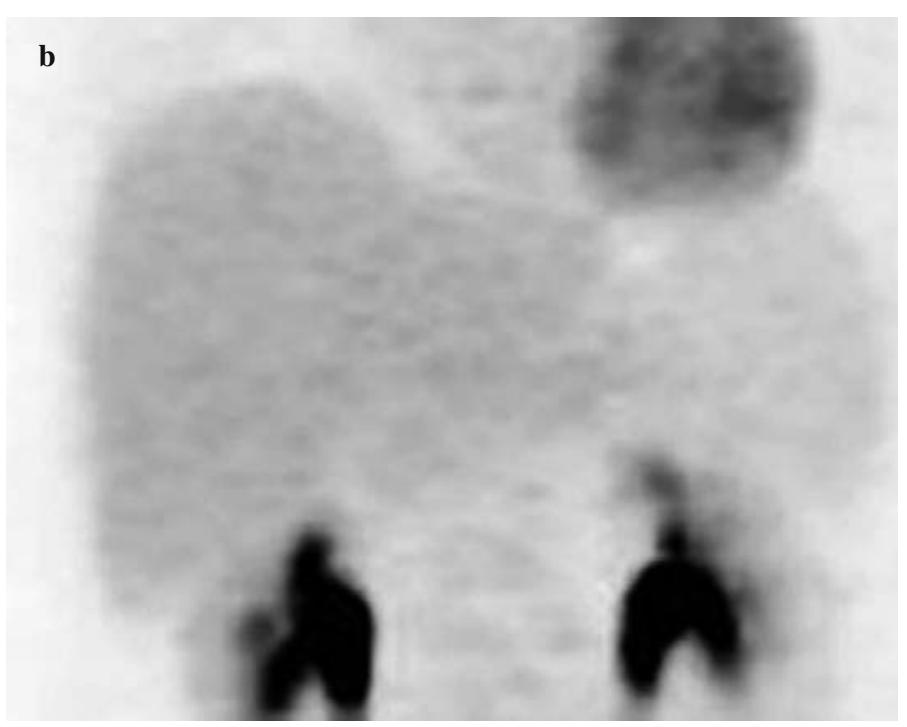

Fig. 4a-c Liver metastasis detected only by computed tomography (CT) in a 66-year-old woman evaluated during staging of colorectal carcinoma. Axial CT scan (a) in the portal phase shows a 7$\mathrm{mm}$ nodular metastatic lesion at hepatic segment VIII. Coronal maximum intensity projection 2[fluorine-18] fluoro-2-deoxy-D-glucose positron emission tomography (MIP ${ }^{18} \mathrm{~F}-\mathrm{FDG}$-PET) scan (b) does not reveal focal uptake of FDG in the liver. Axial FDG-PET/CT fusion image (c) fails to show focal uptake of FDG at the level of the CT finding.

Fig. 4a-c Paziente di 66 anni esaminata in fase di stadiazione per carcinoma del colon-retto, con metastasi epatica evidente solo all'esame TC. a La scansione TC, acquisita in fase portale, documenta la presenza di una lesione focale di natura secondaria di $7 \mathrm{~mm}$ di diametro localizzata a livello dell'VIII segmento epatico. $\boldsymbol{b}$ L'immagine coronale MIP-FDG-PET non mette in evidenza iperfissazione del tracciante in sede epatica. $\boldsymbol{c}$ L'immagine di fusione PET/TC assiale con mdc non documenta un aumento focale di captazione del FDG nella sede della lesione metastatica.

Table 2 Sensitivity, specificity, positive predictive value, negative predictive value and accuracy of 2-[fluorine-18] fluoro-2-deoxy-D-glucose positron emission tomography $\left({ }^{18} \mathrm{~F}\right.$-FDG-PET) in the detection of hepatic metastases in patients with colorectal cancer

\begin{tabular}{llll}
\hline PET & Percent & $95 \%$ confidence interval (CI) \\
\hline Sensitivity & 94.05 & 91.52 & 96.58 \\
Specificity & 91.60 & 86.85 & 96.35 \\
Positive predictive value (PPV) & 96.64 & 94.68 & 98.59 \\
Negative predictive value (NPV) & 85.71 & 79.92 & 91.51 \\
Accuracy & 93.36 & 91.10 & 95.62 \\
\hline
\end{tabular}

Tabella 2 Sensibilità, specificità, valore predittivo positivo, valore predittivo negativo ed accuratezza diagnostica della ${ }^{18}$ FDG-PET nel riconoscimento delle metastasi epatiche in pazienti con carcinoma colo-rettale

\begin{tabular}{llll}
\hline PET & Percentuale & Intervallo di confidenza (IC) $95 \%$ \\
\hline Sensibilità & 94,05 & 91,52 & 96,58 \\
Specificità & 91,60 & 86,85 & 96,35 \\
Valore predittivo positivo (VPP) & 96,64 & 94,68 & 98,59 \\
Valore predittivo negativo (VPN) & 85,71 & 79,92 & 91,51 \\
Accuratezza & 93,36 & 91,10 & 95,62 \\
\hline
\end{tabular}


Table 3 Sensitivity, specificity, positive predictive value, negative predictive value and accuracy of computed tomography (CT) in the detection of hepatic metastases in patients with colorectal cancer

\begin{tabular}{llll}
\hline CT & Percent & $95 \%$ confidence interval (CI) \\
\hline Sensitivity & 91.07 & 88.02 & 94.12 \\
Specificity & 95.42 & 91.84 & 99.00 \\
Positive predictive value (PPV) & 98.08 & 96.55 & 99.60 \\
Negative predictive value (NPV) & 80.65 & 74.43 & 86.86 \\
Accuracy & 92.29 & 89.87 & 94.71 \\
\hline
\end{tabular}

Tabella 3 Sensibilità, specificità, valore predittivo positivo, valore predittivo negativo ed accuratezza diagnostica della TC nel riconoscimento delle metastasi epatiche in pazienti con carcinoma colo-rettale

\begin{tabular}{llll}
\hline TC & Percentuale & Intervallo di confidenza (IC) $95 \%$ \\
\hline Sensibilità & 91,07 & 88,02 & 94,12 \\
Specificità & 95,42 & 91,84 & 99,00 \\
Valore predittivo positivo (VPP) & 98,08 & 96,55 & 99,60 \\
Valore predittivo negativo (VPN) & 80,65 & 74,43 & 86,86 \\
Accuratezza & 92,29 & 89,87 & 94,71 \\
\hline
\end{tabular}

Table 4 Sensitivity, specificity, positive predictive value, negative predictive value and accuracy of 2-[fluorine-18] fluoro-2-deoxy-D-glucose positron emission tomography $\left({ }^{18}\right.$ F-FDG-PET) and computed tomography (CT) in the detection of hepatic metastases in patients with colorectal cancer

\begin{tabular}{llll}
\hline PET/CT & Percent & $95 \%$ confidence interval (CI) \\
\hline Sensitivity & 97.92 & 96.39 & 99.44 \\
Specificity & 97.71 & 95.15 & 100 \\
Positive predictive value (PPV) & 99.10 & 98.08 & 100 \\
Negative predictive value (NPV) & 94.81 & 91.07 & 98.56 \\
Accuracy & 97.86 & 96.55 & 99.17 \\
\hline
\end{tabular}

Tabella 4 Sensibilità, specificità, valore predittivo positivo, valore predittivo negativo ed accuratezza diagnostica della ${ }^{18}$ FDG-PET-TC nel riconoscimento delle metastasi epatiche in pazienti con carcinoma colo-rettale

\begin{tabular}{llll}
\hline PET/TC & Percentuale & Intervallo di confidenza (IC) $95 \%$ \\
\hline Sensibilità & 97,92 & 96,39 & 99,44 \\
Specificità & 97,71 & 95,15 & 100 \\
Valore predittivo positivo (VPP) & 99,10 & 98,08 & 100 \\
Valore predittivo negativo (VPN) & 94,81 & 91,07 & 98,56 \\
Accuratezza & 97,86 & 96,55 & 99,17 \\
\hline
\end{tabular}

significant difference in sensitivity and accuracy was obtained relative to the combined technique (PET/CT) vs CT. There was no statistically significant difference in sensitivity, specificity or accuracy between the individual techniques (PET vs CT) (Table 5).

\section{Discussion}

Colorectal cancer is one of the most common cancers in Western countries, and liver metastases from the tumour are an enormous challenge for clinical oncology. A third of

\section{Discussione}

Il tumore del colon-retto è una delle neoplasie più frequenti nei paesi occidentali e le metastasi epatiche di tale neoplasia rappresentano un grande problema nell'oncologia clinica. Un terzo dei pazienti con neoplasia dell'intestino ha localizzazioni secondarie epatiche già al momento della diagnosi e il 20\% dei pazienti le svilupperà in seguito. Il trattamento chirurgico delle metastasi, associato alla chemioterapia, rappresenta la scelta terapeutica in grado di garantire la sopravvivenza più soddisfacente, sebbene solamente un terzo delle metastasi epatiche siano trattabili. 
Table $5 \mathrm{Z}$ test results comparing 2-[fluorine-18] fluoro-2-deoxy-D-glucose positron emission tomography $\left({ }^{18} \mathrm{~F}-\mathrm{FDG}-\mathrm{PET}\right)$ and computed tomography (CT) and ${ }^{18} \mathrm{FDG}$-PET/CT in the detection of hepatic metastases in patients with colorectal cancer

\begin{tabular}{llll}
\hline Z test & & & \\
\hline Diagnostic technique & Z test & Z test absolute value & $p<0.05$ \\
\hline PET vs CT & & & \\
Sensitivity & 1.0607 & 1.0607 & $\mathrm{NS}$ \\
Specificity & -1.6092 & 1.6092 & $\mathrm{NS}$ \\
Accuracy & 0.3969 & 0.3969 & $\mathrm{NS}$ \\
PET vs PET/CT & & & $\mathrm{S}$ \\
Sensitivity & -2.1550 & 2.1550 & $\mathrm{~S}$ \\
Specificity & -3.0544 & 3.0544 & $\mathrm{~S}$ \\
Accuracy & -2.4231 & 2.4231 & $\mathrm{~S}$ \\
CT vs PET/CT & & & $\mathrm{NS}$ \\
Sensitivity & -2.3512 & 2.3512 & $\mathrm{~S}$ \\
Specificity & -1.0801 & 1.0801 & \\
Accuracy & -2.2359 & 2.2359 & \\
\hline
\end{tabular}

$N S$, not statistically significant; $S$, statistically significant

Tabella 5 Risultati test $Z$ confrontando $l{ }^{18} \mathrm{FDG}$-PET, la TC e la ${ }^{18} \mathrm{FDG}$-PET/TC nel riconoscimento delle metastasi epatiche in pazienti con carcinoma colo-rettale

\begin{tabular}{llll}
\hline Test $Z$ & & & \\
\hline Tecnica diagnostica & Test Z & Test Z valore assoluto & $p<0,05$ \\
\hline PET vs TC & & & \\
Sensibilità & 1,0607 & 1,0607 & $N S$ \\
Specificità & $-1,6092$ & 1,6092 & $N S$ \\
Accuratezza & 0,3969 & 0,3969 & $N S$ \\
PET vs PET/TC & & & $S$ \\
Sensibilità & $-2,1550$ & 2,1550 & $S$ \\
Specificità & $-3,0544$ & 3,0544 & $S$ \\
Accuratezza & $-2,4231$ & 2,4231 & \\
TC vs PET/TC & & & \\
Sensibilità & $-2,3512$ & 2,3512 & \\
Specificità & $-1,0801$ & 1,0801 & $S$ \\
Accuratezza & $-2,2359$ & 2,2359 & $S$ \\
\hline
\end{tabular}

NS, non statisticamente significativo; $S$, statisticamente significativo

patients with colorectal cancer have secondary liver lesions at diagnosis, and $20 \%$ of patients develop them thereafter. Surgical excision of the lesions combined with chemotherapy is the treatment strategy able to guarantee a more satisfactory survival rate, even though only one third of liver metastases are treatable.

In the study of colorectal cancer, PET has been utilised mainly to clarify the nature of dubious lesions identified on a first-line examination such as CT or when - especially during follow-up - an increase in a tumour marker is seen in the absence of lesions demonstrated by the more conventional diagnostic examinations [14]. The high level of clinical transferability of the information provided by PET
Nello studio delle neoplasie del colon-retto, la PET è stata di solito impiegata allo scopo di chiarire la natura di lesioni dubbie già evidenziate da esami di I livello come la TC oppure quando, soprattutto in corso di follow-up, si osservava un incremento di un marcatore oncologico, in assenza di localizzazioni documentate dai più convenzionali esami diagnostici [14]. L'elevata trasferibilità clinica dell'informazione fornita dalla PET dipende dalla capacità di valutare il grado di attività metabolica dei tessuti tumorali, non considerando esclusivamente i parametri morfologici e dimensionali delle lesioni.

Numerosi studi hanno dimostrato che il tessuto neoplastico in rapida crescita utilizza il glucosio come substrato ai 
depends on its ability to evaluate the degree of metabolic activity of the tumour tissue and not only the morphology and size of the lesions.

Numerous studies have shown that rapidly growing neoplastic tissue utilises glucose as a substrate for energy needs, thus producing an increased uptake of ${ }^{18} \mathrm{~F}$-FDG [15]. Even though the tracer is not tumour-cell specific, ${ }^{18} \mathrm{~F}$-FDG is widely used in the study of many malignant diseases [16, 17], as it is considered better than conventional imaging in identifying primary or secondary tumours.

In our study, we sought to compare the functional and morphological information obtained from ${ }^{18} \mathrm{~F}$-FDG PET and $\mathrm{CT}$ with that provided by PET/CT in the evaluation of secondary hepatic lesions. Our results showed similar sensitivity, specificity and diagnostic accuracy values between the two modalities and an improvement when the two techniques are used in combination. The $\mathrm{Z}$ test failed to demonstrate statistically significant differences between the two individual modalities and showed that PET and $\mathrm{CT}$ were very much alike in their detection of liver metastases. In contrast, combined PET/CT proved superior to PET and CT used individually, with statistically significant differences in all the parameters studied except CT specificity.

In our study there was greater concordance among imaging modalities in terms of sensitivity, specificity and diagnostic accuracy than reported in the literature, as most studies to date have used CT without contrast enhancement, which does not enable visualisation of many liver metastases [17-19]. Even if secondary hepatic lesions show evident focal uptake of ${ }^{18} \mathrm{~F}$-FDG on the PET images, these lesions often cannot be identified on baseline CT images. In our study, contrast-enhanced CT improved diagnostic reliability above all for the purposes of correct preoperative staging without negatively influencing the qualitative and quantitative data obtained at PET.

Although PET and CT are shown by the data to be equivalent in their ability to identify secondary hepatic lesions, the two modalities are evidently complementary. In agreement with the literature, the integration of PET with CT makes possible the combination of metabolic data and morphological imaging, thus enabling an accurate definition of the extension of disease at the time of diagnosis [20, 21]. The combined technique in fact offers improved localisation of the foci of radiotracer uptake, differentiating the increases in metabolic activity due to physiological or inflammatory processes from those of neoplastic origin [22, 23]. In addition, it improves the localisation and characterisation of lesions [24], thus reducing the number of lesions of uncertain or indefinite origin.

The evaluation of treatment response is also improved by not relying solely on size criteria. Indeed, studies have shown that the reduction in the number of malignant cells fini energetici, determinando un aumento dell'uptake del ${ }^{18}$ F-FDG [15]. Sebbene tale tracciante non sia specifico della cellula tumorale, $l a{ }^{18} \mathrm{~F}$-FDG-PET risulta largamente utilizzata nello studio di molte patologie neoplastiche [16, 17], in quanto considerata migliore dell'imaging convenzionale nell'identificazione della patologia tumorale primitiva o secondaria.

Nel nostro studio abbiamo voluto comparare le informazioni funzionali e morfologiche ottenute rispettivamente mediante la ${ }^{18} F-F D G-P E T$ e la TC, con quelle fornite dalla PET/TC, nella valutazione delle lesioni secondarie epatiche. I risultati da noi ottenuti hanno evidenziato valori sovrapponibili di sensibilità, specificità e accuratezza diagnostica tra le due metodiche poste a confronto ed un miglioramento, se considerate le due tecniche associate. Il test $Z$ non ha identificato differenze statisticamente significative tra le due singole tecniche in esame dimostrando una sostanziale equivalenza della PET e della TC nella identificazione delle localizzazioni secondarie epatiche. Diversamente la tecnica combinata PET/TC è risultata superiore alle tecniche diagnostiche PET e TC applicate singolarmente, con valori di significatività statistica in tutti i parametri studiati tranne che per la specificità TC.

Nel nostro studio, le metodiche mostrano una concordanza con valori di sensibilità, specificità ed accuratezza superiori ai dati della letteratura poiché, la maggior parte degli studi finora effettuati utilizzano la TC senza la somministrazione di MdC organo-iodato, che non permette la visualizzazione di molte metastasi epatiche [17-19]. Anche se le localizzazioni secondarie epatiche mostrano una evidente ipercaptazione di ${ }^{18} F-F D G$ alle immagini PET, spesso le lesioni non vengono evidenziate alla TC basale. Nel nostro studio l'esame TC effettuato con la somministrazione endovenosa di MdC organo-iodato, ha migliorato l'attendibilità diagnostica, ai fini soprattutto di un corretto staging pre-operatorio senza inficiare le informazioni qualitative e quantitative ottenute alla PET.

Sebbene la PET e la TC risultano, dai dati di questo lavoro, equivalenti nella capacità di identificare localizzazioni secondarie epatiche, appare chiaro che le due metodiche sono tra loro complementari. In accordo con i dati della letteratura, la possibilità di integrare la PET con la $T C$ consente di combinare l'informazione metabolica con il dato anatomico permettendo, al momento della diagnosi, un'accurata definizione della estensione di malattia [20, 21]. La tecnica combinata permette infatti una migliore localizzazione dei foci di uptake, differenziando gli aumenti di attività metabolica di natura fisiologica o flogistica da quelli di natura neoplastica [22, 23]. Inoltre migliora la localizzazione delle lesioni ed aumenta la loro caratterizzazione [24], riducendo il numero di lesioni con origine incerta o equivoca.

Migliora anche la valutazione della risposta alla terapia, che sulla base di soli criteri dimensionali può risultare inaccurata. Infatti, è noto che la riduzione del numero delle 
may not lead to a significant reduction in lesion size, as the neoplastic tissue may be replaced by necrotic tissue or fibrosis, which cannot be differentiated from malignant tissue with conventional diagnostic modalities. In addition, treatment planning may be oriented and/or modified by fusion of the metabolic data provided by PET, which is fundamental for identifying secondary lesions located in the peritoneum, mesentery and lymph nodes [25] where CT shows its major limitations - with the morphological data provided by $\mathrm{CT}$ - which makes possible the examination of fundamental anatomical structures such as the portal vein, the vena cava or the bile ducts [26].

Accurate preoperative staging is crucial for determining the optimal therapeutic approach in each patient [27]. The combined technique, which is able to perform precise tumour staging, can orient or rule out the need for further procedures, thus changing the treatment plan [18, 28-30]. PET/CT has proven particularly effective even when clinical or imaging techniques fail to demonstrate disease recurrence in the presence of a progressive increase in tumour markers, thus leading to an earlier diagnosis with a positive impact on patient survival. The change in the uptake of ${ }^{18} \mathrm{~F}$ FDG in fact correlates with serum carcinoembryonic antigen levels, the increase in which is a common finding in these patients [25].

The combined modality also minimises the intrinsic limitations of the two techniques responsible for FN findings. In our experience, at CT these are prevalently due to the lack of evident anatomical alterations or vascular abnormalities in the presence of increased neoplastic metabolic activity (Fig. 3), and at PET to the presence of necrotic areas with no radiotracer uptake, mucinous adenocarcinoma metastases [31] or lesions smaller than the technique's resolution power, which instead are identifiable with contrastenhanced CT (Fig. 4).

Although PET is an expensive technique that is not available in all centres, a cost-benefit analysis performed in the United States and Europe showed that PET/CT enables improved patient selection for surgery and as a result is cost effective [32]. Moreover, the use of PET/CT leads to an overall reduction in costs with respect to the separate use of the two imaging modalities [33] and improved utilisation of the diagnostic devices [34]. Lastly, by optimising study protocols, the combined PET/CT examination is also able to reduce the overall dose of radiation delivered to the patient [33] and the overall examination time, thus minimising patient discomfort.

\section{Conclusions}

PET/CT is able to provide a synergy of functional, anatomical and structural information with considerable optimisation cellule neoplastiche può non comportare una significativa riduzione delle dimensioni della lesione in quanto il tessuto tumorale può essere sostituito da tessuto necrotico o fibroso, che risulta indistinguibile alla diagnostica convenzionale dal tessuto maligno. Inoltre la fusione del dato metabolico, fornito dalla PET, fondamentale per evidenziare le localizzazioni secondarie a livello peritoneale, mesenteriale e linfonodale [25] in cui la TC mostra il suo maggior limite, con il dato morfologico, fornito dalla TC, che permette di esaminare strutture anatomiche fondamentali quali la vena porta, la vena cava o le vie biliari, guida elo modifica il planning terapeutico [26].

Un accurato staging preoperatorio è importante per determinare l'approccio terapeutico ottimale in ogni paziente [27]. E la tecnica combinata, in grado di effettuare una precisa stadiazione tumorale, può guidare o escludere la necessità di ulteriori procedure, cambiando la modalità di trattamento [18, 28-30]. La PET/TC si è dimostrata particolarmente efficace anche quando, in presenza di un innalzamento progressivo dei marcatori tumorali, non era visualizzabile clinicamente o strumentalmente alcuna ripresa di malattia, rendendo possibile un'anticipazione diagnostica, con un aumento potenziale dell'indice di sopravvivenza. Il cambiamento nell'uptake ${ }^{18} F-F D G$ correla infatti con i livelli di CEA sierico, la cui elevazione sine materia è di frequente riscontro in questi pazienti [25].

Si minimizzano, inoltre, i limiti intrinseci delle due metodiche responsabili dei reperti FN. Questi, nella nostra esperienza, sono dovuti prevalentemente per la TC alla assenza di evidenti alterazioni anatomiche o di anomala vascolarizzazione in presenza di aree di aumentata attività metabolica neoplastica (Fig. 3); per la PET alla presenza di aree necrotiche non captanti l'FDG o a lesioni di dimensioni inferiori al suo potere di risoluzione riconoscibili invece alla TC con MdC (Fig. 4), o, come descritto in letteratura, alla presenza di metastasi da adenocarcinoma mucinoso [31].

Nonostante la PET sia una tecnica costosa e non disponibile in tutti i centri, una valutazione costo-beneficio effettuata sia in USA che in Europa ha mostrato come la PET/TC permetta una migliore selezione dei pazienti candidati alla chirurgia e sia pertanto "cost-effective" [32]. Inoltre con la PET/TC si ottiene la riduzione complessiva dei costi rispetto all'impiego separato delle due metodiche [33] ed il migliore utilizzo delle apparecchiature diagnostiche [34]. Infine, ottimizzando i protocolli di studio, con l'esame combinato PET/TC si riduce anche la dose complessiva di radiazioni ionizzanti assorbita [33], i tempi globali di esecuzione delle indagini, apportando un minore disagio al paziente.

\section{Conclusioni}

Con la PET/TC si ottiene un sinergismo informativo funzionale-anatomico-strutturale con una notevole ottimizzazione 
of the data obtained with the two modalities taken individually. The technique therefore plays a crucial role in the staging and follow-up of cancer patients. The use of PET/CT may be instrumental in reaching an earlier diagnosis, which influences patient management by prompting the performance of procedures of proven effectiveness or the nonperformance of procedures that may prove ineffective or even harmful. PET/CT offers excellent diagnostic performance in terms of sensitivity and specificity and can modify a patient's treatment protocol. Lastly, the technique has the characteristic of an all-in-one examination if performed with contrast medium, thus leading to significant economic savings. delle informazioni derivanti dalle due modalità PET e TC prese singolarmente. Si evidenzia quindi il ruolo fondamentale che essa riveste nella stadiazione e nel follow-up delle neoplasie. La PET/TC può consentire tra l'altro un'anticipazione diagnostica che incide sulla gestione del paziente attraverso l'esecuzione di interventi di documentata efficacia o la non esecuzione di interventi che potrebbero risultare inefficaci o addirittura dannosi. La PET/TC è in grado di offrire una performance diagnostica ottimale in termini di sensibilità e specificità, potendo modificare l'iter terapeutico dei pazienti, rivestendo anche caratteri di indagine unica di elezione, se eseguita con MdC organo iodato, con conseguenti notevoli risparmi economici.

Conflict of interest statement: The authors declare that they have no conflict of interest to the publication of this article.

\section{References/Bibliografia}

1. Parker SL, Tong T, Bolden S, Wingo PA (1997) Cancer statistics. CA Cancer J Clin 47:5-27

2. Piano oncologico nazionale (20042006) Commissione Oncologica Nazionale - Ministero Salute. D.M. 26-5-2004 p.5

3. Abdel-Nabi H, Doerr RJ, Lamonica DM et al (1998) Staging of primary colorectal carcinomas with fluorine-18 fluorodeoxyglucose whole-body PET: correlation with histopathologic and CT findings. Radiology 206:755-760

4. Arulampalam TH, Francis DL, Visvikis D et al (2004) FDG-PET for the preoperative evaluation of colorectal liver metastases. Eur J Surg Oncol 30:286-291

5. Fong Y, Cohen AM, Fortner JG et al (1997) Liver resection for colorectal metastases. J Clin Oncol 15:938-946

6. Wanebo HJ, Chu QD, Vezeridis MP, Soderberg C (1996) Patient selection for hepatic resection of colorectal metastases. Arch Surg 131:322-329

7. Selzner M, Hany TF, Wildbrett P et al (2004) Does the novel PET/CT imaging modality impact on the treatment of patients with metastatic colorectal cancer of the liver? Ann Surg 240:1027-1034

8. Gearhart SL, Frassica D, Rosen R et al (2006) Improved staging with pretreatment positron emission tomography/computed tomography in low rectal cancer. Ann Surg Oncol 13:397-404
9. Kim EE, Chung SK, Haynie TP et al (1992) Differentiation of residual or recurrent tumors from post-treatment changes with F18 FDG PET. Radiographics 12:269-279

10. Rohren EM, Turkington TG, Coleman RE (2004) Clinical applications of PET in oncology. Radiology 231:305-332

11. Townsend DW, Cherry SR (2001) Combining anatomy and function: the path to true image fusion. Eur Radiol 11:1968-1974

12. Hutton BF, Braun M (2003) Software for image registration: algorithms, accuracy, efficacy. Semin Nucl Med 33:180-192

13. Townsend DW, Beyer T, Blodgett TM (2003) PET/CT scanners: a hardware approach to image fusion. Semin Nucl Med 33:193-204

14. Pauwels EK, McCready VR, Stoot JH, van Deurzen DF (1998) The mechanism of accumulation of tumourlocalising radiopharmaceuticals. Eur J Nucl Med 25:277-305

15. Wahl RL, Hutchins GD, Buchsbaum DJ et al (1991) 18 F-2-deoxy-2-fluoroD-glucose uptake into human tumor xenografts. Feasibility studies for cancer imaging with positron-emission tomography. Cancer 67:1544-1550

16. Lai CH, Yen TC, Chang TC (2007) Positron-emission tomography imaging for gynecologic malignancy. Curr Opin Obstet Gynecol 19:37-41

17. Kostakoglu L, Agress H Jr, Goldsmith SJ (2003) Clinical role of FDG PET in evaluation of cancer patients. Radiographics 23:315-340
18. Fong Y, Saldinger PF, Akhurst T et al (1999) Utility of 18F-FDG positron emission tomography scanning on selection of patients for resection of hepatic colorectal metastases. Am J Surg 178:282-287

19. Imdahl A, Reinhardt MJ, Nitzsche EU et al (2000) Impact of 18F-FDGpositron emission tomography for decision making in colorectal cancer recurrences. Arch Surg 385:129-134

20. Wiering B, Ruers TJ, Oyen WJ (2004) Role of FDG-PET in the diagnosis and treatment of colorectal liver metastases. Expert Rev Anticancer Ther 4:607-613

21. Kim JH, Czernin J, Allen-Auerbach MS et al (2005) Comparison between 18 F-FDG PET, in-line PET/CT, and software fusion for restaging of recurrent colorectal cancer. J Nucl Med 46:587-595

22. Martinelli M, Townsend D, Meltzer C, Villemagne V (2000) Survey of results of whole body imaging using the PET/CT at the University of Pittsburgh Medical Center PET Facility. Clin Positron Imaging 3:161

23. Charron M, Beyer T, Bohnen NN et al (2000) Image analysis in patients with cancer studied with a combined PET and CT scanner. Clin Nucl Med 25:905-910

24. Cohade C, Osman M, Leal J, Wahl RL (2003) Direct comparison of (18)FFDG PET and PET/CT in patients with colorectal carcinoma. J Nucl Med 44:1797-1803 
25. Steele G Jr, Bleday R, Mayer RJ et al (1991) A prospective evaluation of hepatic resection for colorectal carcinoma metastases to the liver: Gastrointestinal Tumor Study Group Protocol 6584. J Clin Oncol 9:1105-1112

26. Kapoor V, McCook BM, Torok FS (2004) An introduction to PET-CT imaging. Radiographics 24:523-543

27. Heriot AG, Grundy A, Kumar D (1999) Preoperative staging of rectal carcinoma. Br J Surg 86:17-28

28. Delbeke D, Martin WH (2004) PET and PET-CT for evaluation of colorectal carcinoma. Semin Nucl Med 34:209-223
29. Rohren EM, Paulson EK, Hagge R et al (2002) The role of F-18 FDG positron emission tomography in preoperative assessment of the liver in patients being considered for curative resection of hepatic metastases from colorectal cancer. Clin Nucl Med 27:550-555

30. Delbeke D, Martin WH, Patton JA, Sandler MP (2001) Value of iterative reconstruction, attenuation correction, and image fusion in the interpretation of FDG PET images with an integrated dual-head coincidence camera and Xray-based attenuation maps. Radiology 218:163-171

31. Flamen P (2002) Positron emission tomography in colorectal cancer. Best Pract Res Clin Gastroenterol 16:237-251
32. Park KC, Schwimmer J, Shepherd JE et al (2001) Decision analysis for the costeffective management of recurrent colorectal cancer. Ann Surg 233:310-319

33. Berthelsen AK, Holm S, Loft A et al (2005) PET/CT with intravenous contrast cam be used for PET attenuation correction in cancer patients. Eur J Nucl Med Mol Imaging 32:1167-1175

34. Czernin J, Schelbert H (2004) PET/CT imaging: facts, opinions, hopes, and questions. J Nucl Med 45:1S-3S 